\title{
SCREEN ELEMENT SHAPE "R73" MUTATION
}

\author{
PAP, K.; VUJIC ZILJAK, J.; ZILJAK, I. \& AGIC, D.
}

Abstract: The paper describes research on creating a new shape of screening cell definition that has not even existed to date. Therefore it has not been researched nor applied yet. A novelty of this paper is that unlike former research where one screening shape was treated in the overall reproduction, this paper presents screening that applies an indefinite number of screening models and screening shapes in the same page. The "R73" mutating screen element shape is shown with a newly developed method of screen element shape growth function parameterization and stochastic functionality implementation. The research methods for testing growth function boundary conditions are $2 D$ and $3 D$ mathematical modelling. The mutation parameter has been designed in such a way that its application alters the screen element shape from a symmetric shape to an asymmetric one. Due to this transformation of shape the authors have named them mutants.

Key words: screening, mutation, function, parameterization, security
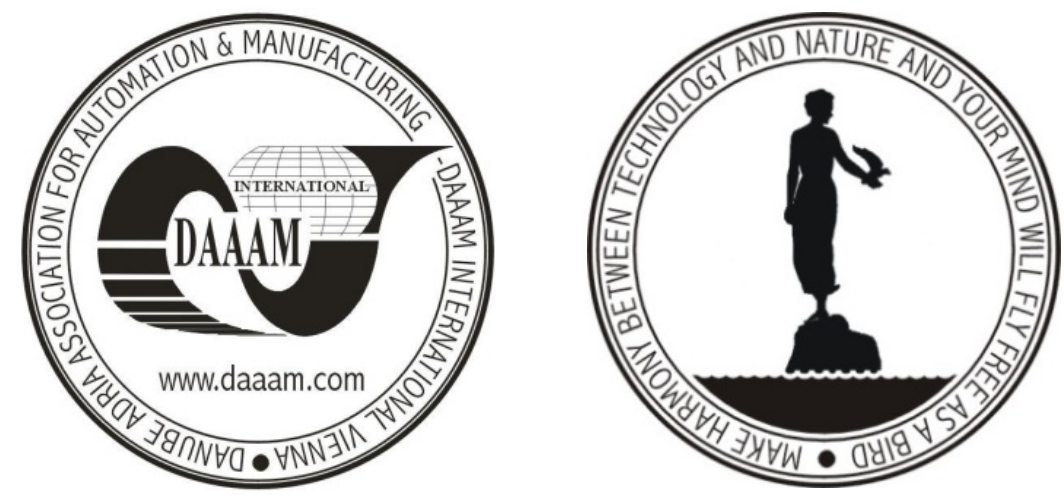

Authors' data: Dr. Sc. Pap, K[laudio]; Dr. Sc. Vujic Ziljak, J[ana]**; Dr. Sc. Ziljak, I[vana]*; Univ.Prof. Agic, D[arko]*, *University of Zagreb Faculty of Graphic Arts, Getaldiceva 2, 10000 Zagreb, Croatia, klaudio.pap@zg.t-com.hr, ivana.ziljak@zg.t-com.hr, darko.agic@grf.hr, **Polytechnic of Informatics and Design, Vrbik 8, 10000 Zagreb, Croatia, janazv@tvz.hr

This Publication has to be referred as: Pap, K[laudio]; Vujic Ziljak, J[ana]; Ziljak, I[vana] \& Agic, D[arko] (2009). Screen Element Shape "R73“" Mutation, Chapter 73 in DAAAM International Scientific Book 2009, pp. 763-770, B. Katalinic (Ed.), Published by DAAAM International, ISBN 978-3-901509-69-8, ISSN 1726-9687, Vienna, Austria

DOI: $10.2507 /$ daaam.scibook.2009.73 